\title{
The Art of Linking: About LINKs-series, a transdisciplinary and international journal
}

\author{
Louis-José Lestocart ${ }^{1}$ \\ "[ingenium] the inborn disposition of the mind through \\ which nature gives the rule to art" \\ Immanuel Kant, Critique of the Power of Judgment, $\$ 46$
}

The concept of Ingenium has been designed by the Neapolitan philosopher and celebrated author of the Principi d'una Scienza Nuova (The New Science, 1744) Giambattista Vico (1668-1744) as he rose up against Cartesianism, which he thought was stuck in a descriptive, linear and continuous quagmire (stemming from an inaccurate and inevitably "imperfect" awareness). Ingenium: that is " "the ability to bring to the unity what is separated and multifarious,' but also 'to grasp the relations of things [rerum commensus] [1]."' Coming from the field of rhetoric (most particularly Cicero's rhetoric), ingenium is not to be perceived as a simple instrument for deduction or reflection, but as an inexhaustible and powerful ability for innovation. The "science of ingenium" as a concept indeed covers a wide range of meanings, being both an "object of creation" and an object of understanding/reasoning. "Surely, humans distinguish themselves by their ingenio, this strange ability to discern in order to link up and conjoin." [2] This "science of ingenium" is already what we call today "systems science" or "science of complexity."

If one were to try and attempt, without being vain and ostentatious, LINKs espouses the point of view of one of the key figures of constructivism, the biologist, psychologist, logician and epistemologist Jean Piaget, as expressed in Psychologie et pédagogie (1969) and in Où va l'éducation?: "Knowledge is re-construction. Understanding is invention [3];" "Understanding is invention, or reconstruction through reinvention, and we will have to comply with these requirements if we want, in the future, to make individuals capable of production or creation, and not just repetition [4]." The emblematic poet of Modernity Paul Valéry, for his part, already claimed in his Cahier B 1910 (1924) inserted into Tel Quel I (1941):

"To invent must be like being able to recognize a tune in the monotonous falling of water-drops, in the rhythms of a train and in the regular strokes of an engine...

What's needed, I think, is some - non-specified object or kernel or substance, and a state of mind. There is a part of man that feels alive only when creating: I invent, therefore I am. The general run of inventions belongs to this type: a sequence of successive, almost continuous deformations of the given material, and a threshold - a sudden perception of the future of one of the states.

Future, that is, usable value, significant value, singularity [5]."

Vico, who proposed a "new Discourse on Method," introduced in the De Nostri temporis studiorum ratione (On the Study Methods of Our Time, 1709), as well as in three other Treaties [6-8], this idea of a creative ability represented by the Latin ingenium - ingenio into Italian, euphuia into Greek (the "proper natural ability"). This ability - or disposition - this conception exactly illustrates a notion of conjunction (of links then) that makes possible the accession to understanding and to the signification of the world phenomena, and therefore enables to construct a knowledge in every field. Vico thus argues "that one cannot reach truth without ingenium and without ingenii acumen [9]."2 "The concept of ingenium introduces [...] a factor of individual talent which is rather stylistic-natured, in that it appeals to a global form of invention [10]" This "ability to grasp the connections between separate things or aspects, [and,] among other things, to create metaphors [11]," is also reflected in LINKs. LINKs, as a review, meets the needs of creativity before the needs of the intellect. The very idea of conjunction between different fields and knowledge produced by the most heterogeneous researches - which form the framework of an original composition of sometimes new themes and patterns - de facto infuses art more than reflection, randomness or stochasticity more than calculation and possibly much more. For, as the Austrian gestaltist psychologist Christian von Ehrenfels (1859-1932) put it: "the whole is greater than the sum of its parts," new properties emerge because of the aggregation, properties that can additionally have a retroactive effect on the various parts. ${ }^{3}$

\footnotetext{
${ }^{1}$ Louis-José Lestocart is the editorial director of the transdisciplinary journal LINKs. This paper first appeared in French in LINKs 1: http://links-series.com.

${ }^{2}$ Acumen (literally the point of the sword), or la figure de l'esprit (the figure of the mind), refers to the acuteness, the insightfulness, the sharpness and pervasion of the ingenium. Combined with the acumen, the ingenium forms the "ability to perceive differences, the perspicacia."

${ }^{3}$ One can nonetheless find this idea throughout the history - and already in Aristotle. In Über Gestaltqualitäten (On the Qualities of Form, 1890), Ehrenfels argues that one cannot reduce a received totality to the sum of the parts that compose it. To assert his demonstration, he proposes an example in the musical field: if one transposes a melody in another clef, he notes, the audience still
} 
LINKS wishes to ascertain this powerful ability and valorize inventiveness, as a witness and a potential engaged actor in the modes of understanding and in the contemporary theoretical models. As Valéry says: "A man of wit is a man who has a highly developed sense of the multiplicity of answers, a superfast sensitive response to circumstances [12]." This man the poet speaks about shows a creative spirit that produces resemblances [13]. As Vico assures, he achieves to detect "in widely diverse things some connection through which they get united [6]." It ensues from this an essence of discovery within a synthesis. This Art of linking is also the English wit and flash of wit, and even humour, if not nonsense, a kind of randomness - the retort arising unexpectedly, as a matter of chance. And it is also the German Witz, equally very similar to the Vichian ingenium, which "constitutes the other name and 'concept' of knowledge, or rather the name and 'concept' of knowledge that is other: of knowledge that is other than the knowledge of analytic and predicative discursivity [13]." This wit - also to be found in the work of the English philosopher, writer and politician Anthony Ashley-Cooper (1671-1713), $3^{\text {rd }}$ Earl of Shaftesbury, who authored Sensus Communis, An Essay on the Freedom of Wit and Humor - A Letter to a Friend (1709) - and this Witz - as in the writings of Immanuel Kant and above all of the German philosopher, critic and writer Friedrich Schlegel (17721829) - preserve something of the ingenium's power of metaphorical invention in so far as they give "the ability to combine the most diverse forces on a dynamic mode, showing new perspectives [14]."

Being fundamentally "involontary" in nature, the Witz belongs to both cognitive and productive categories, and "is [thus] basically qualified as a unification of heterogeneous elements; that is, both as a substitute for true conception (which occurs in and by the homogeneous) and as the double of judgment (which links together the heterogeneous only under the control of the homogeneous)."[13] In this Witz at the origin of a "transcendental" Romanticism where "the categories of Logic, in order to gain access to a level of awareness in which contradictory elements can be linked up and harmonized beyond their incompatibility from a rational point of view [14]," occurs this assumption that implies that "the Witz can only be expressed in a fragmentary form due to the brief and elusive nature of its emergence." [14] It can be seen as an "explosion of compressed mind [13]" or a true "deflagration." That is to say as the Erlebnis - sudden appearance, brilliance References that will become "patient savoir" (patient knowledge) [15].

For Schlegel, Witz, seen as activism, has thus three dimensions: a "combinatorial faculty; [a] poetic proposition; [an] opening on mystery [16]."

"In a closed world where one thought 'all is said and done,' the Witz operation, coming back to the elements, gives way to new relations. At the beginning of his essay 'Über Lessing', , Schlegel stresses the adversarial structure of the 'all is said and done,' which he does not attribute to La Bruyère but to Voltaire: for - he says while finding it already in Terence - such a statement also immediately applies to itself. One then must instead use the inverse fomula: 'nothing has yet truly been said' [11]."

If we go back to Vico: " "[...] ingenium through which man has the ability to contemplate and make objects similar to those of his contemplation' [6];" "Ingenium is the ability of inventio which is an act of creation and thereby of knowledge, and this ability is all the more advanced than creators 'step over what is under their feet and go and seek far away suitable connections for their subjects' [6]."

In another meaning, the ingenium, an innate element of productivity, creativity and ability to transcend and transform what is given - whether it is intellectual speculation or poetic and artistic creation - is "nourished by what is best in human imagination, which would otherwise be dried up by a purely intellectual exercise [2]." 5 The ingenium invents, creates, finding almost naturally (through randomness and out of the planned project and reasons adduced of knowledge) what unifies. It allows " deciphering the world' that, without it, would stay mute and unknown [16]." Through it, the human mind is going to know and to conceive, poetically or poietically, "building a world of forms," the multiple understandings of these "makings," at times "new and surprising," which it might be able to "embellish with new and more poetic features, and in this way... make them its [6]."

Translated from French by Johanna Blayac, reviewed by Laurence Brière \& Tony Chung.

[1] D. Luglio, "Mare antiquissimum. La réponse de G. B. Vico à la Querelle des Anciens et des Modernes," Babel 2 (1997). Text on line: http://journals.openedition.org/babel/2676.

recognizes the melody, whilst all the notes have changed. The melody itself has properties that cannot be reduced to the sum of its parts: the melody is perceived as a global form. It is thus the ratio which "leads" the melody, more than the notes themselves.
${ }^{4}$ Gotthold Lessing (1729-1781), German author, critic and playwright.

5 "A powerful ingenium is required, writes Cicero, to take one's mind off the senses, and one's thought off the habit." Tusculanes, I, 16, 38 . 
[2] See Giambattista Vico, La méthode des études de notre temps, translation, introduction and notes by Alain Pons (Les Belles Lettres, Paris, 2010). Text on line:

http://www.mcxapc.org/docs/conseilscient/0511vico_pons.pdf

[3] Jean Piaget, Psychologie et pédagogie (Gonthiers Denoël, Paris, 1969).

[4] Jean Piaget, Où va l'éducation? (Denoël, Paris, 1972).

[5] Paul Valéry, Cahiers / Notebooks 2, edited by Brian Stimpson, Paul Gifford, Robert Pickering, translated by Rachel Killick, Robert Pickering, Norma Rinsler et al. (Peter Lang, New York, 2000).

[6] Giambattista Vico, De l'antique sagesse de l'Italie (1710), French translation by Jules Michelet, in Euvres complètes de Jules Michelet, volume des Euvres choisies de Vico (Flammarion, Paris, 1894). Text on line: https://fr.wikisource.org/wiki/De l'antique sagesse de l'Italie.

[7] Giambattista Vico, Principes d'une science nouvelle relative à la nature commune des nations, translation by Alain Pons (Fayard, Paris, 2001).

[8] Giambattista Vico, Institutiones Oratorice (1711).

[9] "Extraits de divers Opuscules ou Lettres de Vico," French translation by Jules Michelet, in Euvres complètes de Jules Michelet, volume des Euvres choisies de Vico (Flammarion, Paris, 1894). Text on line: https://fr.wikisource.org/wiki/Extraits_de_divers_Opuscules_ou_Lettres_de_Vico.

[10] L. Jenny, "Du style comme pratique," Littérature 118 (2000).

[11] D. Thouard, "Qu'est-ce que les Lumières pour le premier Romantisme? Chimie, Witz, maximes et fragments: Friedrich Schlegel et Chamfort" (2003) Text on line: http://www.revue-texto.net/index.php?id=639

[12] Paul Valéry, Cahiers, V, ed. Nicole Celeyrette-Pietri (Gallimard, Paris, 1994).

[13] Philippe Lacoue-Labarthe, Jean-Luc Nancy \& Anne-Marie Lang, L'Absolu littéraire. Théorie de la littérature du romantisme allemand (Editions du Seuil, Paris, 1978); Philippe Lacoue-Labarthe, Jean-Luc Nancy \& AnneMarie Lang, The Literary Absolute: The Theory of Literature in German Romanticism, trans. Philip Barnard \& Cheryl Lester (State University of New York Press, Albany, 1988).

[14] L. Margantin, "Le Witz et l'ironie selon Friedrich Schlegel" (2016) Text on line: http://oeuvresouvertes.net/spip.php?article1706

[15] Julia Kristeva, Le temps sensible. Proust et l'expérience littéraire (Editions Gallimard, Paris, 1994).

[16] N. Brenez, "Jean-Luc Godard, Witz et invention formelle (notes préparatoires sur les rapports entre critique et pouvoir symbolique," Cinémas, Revue d'études cinématographiques 15 n $^{\circ} \mathbf{2 - 3}$ (2005). 